$811.163 .41 ' 221$

https://doi.org/10.18485/kud_kp.2018.ch13

\author{
проф. др Весна Половина \\ Универзитет у Београду \\ Филолошки факултет
}

\title{
О ЈЕЗИКУ У ДИСКУРСУ О ИНТЕРКУЛТУРНОЈ КОМУНИКАЦИЈИ
}

\section{Сажетак}

У раду се разматра место језика и лингвистике у дискурсу о интеркултурној комуникацији. Указује се прво на везу развоја интеркултурне комуникације са наставом страног језика и превођењем. Потом се анализира како се језик приказује с обзиром на укупну стратификацију феномена у култури. Посебна се анализира лексика која у највећој мери одсликава културу неке језичке заједнице. Полазећи од културема, односно речи са изразито културно условљеним значењима, до основних и свакодневних лексема, рад показује да постоји континуум културне условљености, што узрокује стално узајамно преплитање лингвистике и интеркултурне комуникације, а границе између њих се не могу увек смислено повући.

Кључне речи: језик, лексема, лингвистика, интеркултурна комуникација

Циљ овог рада је да се позабави местом језика и начином писања о језику и лингвистици у литератури која се бави интеркултурном комуникацијом, као и интеркултурним феноменима у лингвистици. Почећемо једним краћим историјским освртом, о вези лингвистике и интеркултурне комуникације. 


\section{Из историје развоја лингвистике и интеркултурне комуникације}

Иако је као посебна академска дисциплина интеркултурна комуникација настала у другој половини XX века, када се усталила под разним називима као предмет, па студиј на универзитетском нивоу, у виду асоцијација и стручних друштава, а посебно обимних књига на енглеском језику (Samovar, 2013, као 14. допуњено и проширено издање, или Kiesling, 2005, да наведемо само пар њих) које се баве овом облашћу, свакако да се интерес за интеркултурну комуникацију јављао и кроз друга усмерења и дисциплине - културну антропологију, социолингвистику, филологију, етнологију и сл.

Утицај филологије, наставе страних језика, превођења, лингвистике уопште, на израстање интеркултурне комуникације као дисциплине више је него јасан. Навешћемо ипак како се тај однос наука о језику и интеркултурне комуникације испољава у релевантној литератури кроз неколико примера, а они се односе на два врло практична, примењена аспекта односа језика и интеркултурне комуникације то су настава страних језика и превођење.

Веза наставе страних језика и интеркултурне комуникације природна је у том смислу што потпуна компетенција у усвајању страног језика подразумева и културолошке аспекте комуникација. Отуда не чуди што се у америчкој традицији посебно истиче улога Едварда Хола (Edward T. Hall), америчког антрополога, нарочито његовог рада у Институту за иностране послове при америчкој влади (Foreign Service Institute, од 1951-1955) у којима се будући дипломатски службеници обучавају на интензивним курсевима језика (Rogers et al., 2002). Јасно је, дакле, и овај податак наводимо као врло илустративан, да се развој ове дисциплине може везати за све веће потребе друштва (и не само америчког) од времена II светског рата па надаље, да се што успешније комуницира у свету у коме су сусре- 
ти међу људима и социјалним институцијама све чешћи и разноврснији. Као што се може видети и по данашњем (обновљеном) раду наведеног института, учење страних језика је основа образовања будућих државних службеника који ће радити ван земље. Други пример је из новије, руске литературе. Иако је утицај америчког развоја ове дисциплине и ту неспоран, бар у називу и новијим усмерењима, илустративно је шта каже Тер-Минасова (2008) у свом уџбенику о језику и интеркултурној комуникацији и социјално-историјској условљености интересовања за овај домен. Она истиче, наиме, да су питања односа језика и културе „вечна”, још од давних времена (Тер-Минасова, 2008: 23), али и да данас, у време миграција народа, када су могући културни конфликти, та питања постају све актуелнија. Посебно поглавље (ibid : стр. 30-39) она посвећује међукултурној комуникацији и језику у вези са наставом страних језика, и ситуацији у Русији након „отварања” ове земље ка свету, истичући да се језици морају учити заједно са културом (ibid : стр. 34). Сличне идеје исказане су и у књизи Дурбабе (2016) која, позивајући се на ситуацијум, и глобалну и у нашој земљи, истиче да су међукултурни контакти чињеница и део читаве историје човечанства, али и да модерно доба доноси собом још већу потребу разумевања међу заједницама (Дурбаба, 2006:12-13).

Литература о превођењу такође обилује општим мислима о повезаности језика и културе, иако се то иначе ретко доводи у питање (Nida and Taber, 1982; Nida, 2001; Bassnett, 2005). Тако се Баснетова (Bassnett, 2005), повезујући језик и културу, као и многи други, позива на језичку релативност, цитира Лотманову тврдњу да "No language can exist unless it is steeped in the context of culture; and no culture can exist which does not have at its center, the structure of natural language." (Bassnett, 2005:23) Полазећи од оваквих општих констатација с којима се очито слаже, она даље тврди да, иако је превођење примарно лингвистички процес, оно се може сместити у сферу семиоти- 
ке, јер обухвата и друге, културне знакове и симболе. И даље, цитирајући пре свега низ познатих лингвиста, наводи примере који показују да, рецимо, потпуна, апсолутна језичка синонимија или, у крајњој линији, међујезичка синонимија не постоји, већ се култура нужно мора узети у обзир, односно, да би се могло преводити, прво се мора посматрати и схватити значење и функција исказа унутар културе, како изворног текста тако и превода. Битно је да и она истиче да су све то такође вечита питања и код превођења, али и да су у наше време „експлозија електронских медија и глобализација” (Bassnett, 2005:1) посебно утицали на питања интеркултурне комуникације, јер, наравно све више људи се умрежава и комуницира са припадницима различитих култура.

\section{Место језика у интеркултурној комуникацији}

Говорећи о месту језика, лингвистике и филологије у интеркултурној комуникацији, важно је осврнути се на то како се схвата шта све спада у културу и где је место наведених дисциплина, односно појава којима се оне баве. У том смислу могу се цитирати различите дефиниције, али с обзиром на циљ овог рада, да размотримо метатекст о том односу, посебно нас интересују она одређења која бисмо могли назвати екстензионим дефиницијама, које нуде спискове феномена на које се односи неки термин, у овом случају: култура у дискурсу о интеркултурној комуникацији. Један типичан пример налазимо код Jens Alwood-a (1985:1-2), који даје стратификацију културних феномена, односно димензије културе. То су: куличуролошки обрасии размишльања - што укључује веровања, норме, ставове; обрасии йонашањ а (од начина говора до начина обављања

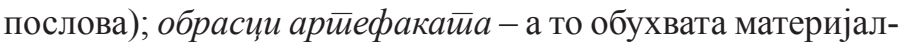
ну културу (да парафразирамо помоћу фразеологизма 'од игле до локомотиве’ - која се обично „може приказати у 
музејима"), и затим све што је човек створио (а не може се ставити у музеје), што се може назвати „ойисциима у ирироgu" (друмови, обрађена земља, итд). Као што видимо, овде је језик само један од начина „понашања”. Међутим, како даље настоји да уведе детаљнију разраду, па када су у питању веровања, знања и ставови, дакле за културолошки битне аспекте који су непходни да би дошло до међусобног разумевања, сматра да је потребно навести и следеће: реалије: географију, историју, религију, политичко-економски систем, храну, одевање и становање; затим есииейску кулйуру, која обухвата: музику, сликарство и књижевност; па ексиерииска знаға; и на крају сйавове и вреgносии $и$, а ови код саговорника могу бити специфични, али и одређени заједничком културом. (Alwood, 1985:15)

Дакле, видимо да се ставови, веровања, знања налазе у овом тексту и на нижем и на вишем нивоу стратификације. То није необично, јер се ради о веома широком схватању заиста комплексног и општег појма. У сличној ситуацији се налазе и аутори који настоје да одреде типове других комплексних појава у друштвеним наукама, рецимо, да се утврде типови или жанрови текстова или дискурса, језички стилови, стилови у уметности, итд. (рецимо, о типовима текстова : Nida, 2001: 91) То се односи и на појам комуникације који може да обухвати не само језик, мада се овоме често признаје централна улога, већ и низ других појава знакова, симбола који преносе информације.

Нешто друкчију слику места језика у интеркултурној комуникацији даје у свом раду Катан (Katan, 2009), смештајући је у контекст превођења као интеркултурне медијације. Он сматра да се приликом превођења медијација између два језика и културе обавља кроз “културне филтере”, моделе којима филтрирамо реалност, јер смо когнитивно, психолошки у немогућности да перцепирамо све појаве у стварности, већ се делови или детаљи те стварности бришу, модификују и генерализују, те су наше слике стварности нека врста нашег, филтрираног доживљаја. С 
обзиром да је наше разумевање и мишљење о стварности условљено стереотипима наше културе, превођење би подразумевало, у неким или можда у свим случајевима, усмеравање пажње на културне моделе који карактеришу поједине језике/културе. Психолошко-антрополошка обојеност модела које он приказује (позивајући се, између осталих, на Малиновског и Е.Т. Хола) најбоље је илустрована поређењем свеколике културе са леденим брегом. Постоји видљива, уочљива култура и мање видљива и приметна, то је она која је „изнад површине воде”. У њу спадају: музика, уметност уопште, храна и пиће, географија, понашање и посебно језик. Одмах испод површине воде су, значи „мање видљиви“: традиција, обичаји, начини понашања, стилови говорења и писања, уметнички стилови и сл., (Katan, 2009: 76-80). Наравно, како сам Хол (Hall: 1959) каже, оваква расподела на „свесно”, „Подсвесно”, „видљиво” и „прикривено”, „експлицитно” или „имплицитно” дато у култури, под великим је и „револуционарним" утицајем Фројда, с тим што је Фројду, који је сматрао да реч више сакрива него што јасно означава, недостајала теорија комуникације (Hall, 1959: 8385). Заједно са лингвистом Џорџом Трагером (са којим је радио у већ поменутом Институту за стране језике) до свог трипартитног модела културе Хол је дошао на основу посматрања како о хронолошком времену говоре амерички говорници енглеског и како се понашају и поимају време. Тако постоји „формално” време које сви познају и у свакодневном животу се усклађују, сматрајући га сасвим природном конвенцијом, „неформално” време које је ситуационо условљено и мање прецизно а илуструју га изрази попут „ускоро”, „касније”, „за минут”, и на крају техничко и научно време са често, за обичног говорника, неразумљивом терминологијом. (Hall,1959: 87)

Овакво виђење „скривености” правих значења језичких и нејезичких симбола, порука и сл., заправо се, као што ћемо видети и даље у тексту, стално провлачи кроз 
литературу. Тако, рецимо, Годар и Вјежбицка (Goddart and Wierzbicka, 2014) говоре о ,разбијању кода речи”, као да постоји површинска, „плића” семантика, семантика „врха леденог брега”, и „дубља”, „прикривена” семантика.

Један од начина посматрања места језика у интеркултурној комуникацији је свакако и супротстављање језичког и ванјезичког (,екстралингвистичког”, невербалног, и сл). Тако је оснивач дисциплине интеркултурне комункације, Е.Т. Хол, остао познат по томе што је увео студије проксемике и хронемике - простора и времена у различитим културама не само као невербалног понашања, већ и у општијем смислу (о односу вербалне и невербалне комуникације шире видети у Panić Cerovski, 2017). Наравно, „невербално” може да обухвати и друге симболе, сигнале попут одеће, предмета које користимо, обичаја приликом обреда, и томе слично, што такође представља начин комуникације. Познат је анегдотални пример нашег обичаја да понудимо слатко госту који треба да узме једну кашичицу истог да се почасти, а ови, не знајући за тај обичај, наставе да узимају и даље. Колико је то битно и у ширем, социјално-културолошком смислу, показују у литератури често навођени примери реклама. Тако, на пример, хризантеме у многим културама, али не и у Америци, асоцирају на смрт (вероватно и зато што се у јесен и зиму јављају). Отуда, реклама за то цвеће мора да се прилагоди различитим културама. Последице обичаја и начина размишљања о неким појавама у датој култури могу бити и озбиљније - веровање, доста распрострањено у словенском свету, да покојнику на одар треба ставити свећу како не би био у вечној тами, да су “чисте” очи важне за његов загробни живот (Толстой, 1985: 185-206), може, рецимо, негативно утицати на одлуку о донирању меког ткива ока преминулог у медицини.

Невербална и вербална комуникација се некада могу, а некада не могу раздвојено посматрати. Доминација неког типа може бити везана и за узраст. Нека врста про- 
то-комуникације са спољашњом средином јавља се чак и пренатално, јер је утврђено на основу експеримената да уобичајени покрети и мелодија мајчиног говора могу деловати смирујуће на рад срца фетуса. То значи да се већ тада јавља осећај за постојање друге особе, а по рођењу, дететов сензомоторни развој, интеракције са другим особама, предметима, додиром, слухом и видом представљају и неку врсту рудиментарне „комуникације”. (Piaget \& Inhelder, 1969, наведено у: Ochs, 2005:81). Отуда одојчад упознаје свет око себе кроз додир, сисање, манипулацијом предмета, али препознају и различите паралингвистичке елементе говора око себе (интензитета, мелодије, опсега гласа старатеља), као и невербалног понашања (осмех, изразе љубави, опасност и сл.)

Поред места језика у укупној стратификацији културних факата и интеркултурној комуникацији, које, како смо видели, може на више начина да се одређује, сматрамо да се као важно поставља и питање места појединих лингвистичких поддисциплина и различитих нивоа језичког испољавања. Стога ћемо у наредном одељку пажњу посветити неким диференцијацијама језичких појава у интеркултурној комуникацији.

\section{Место лексике и граматике у интеркултурној комуникацији}

Са општелингвистичког становишта има извесног смисла одвојити језичке појаве које су кључне за језик лексику и граматику од, рецимо, адекватне употребе језичких форми у неком социјалном и културном контексту, ситуацији. Обично се сматра да су граматичка правила - на пример, категорија граматичког рода - углавном изразито формалне природе, (осим у случају делимичног преклапања, рецимо, природног и граматичког рода), да слагања у роду (у језицима који познају граматички род), сматра се, 
нису везана за значења и семантику. Чињеница је, међутим, да је оваква дистинкција само делимично тачна јер и граматика и лексика одражавају у извесној мери семантичка и функционална својства анализираних језичких појава.

Последице наведеног поимања језика, где постоји „ужи”, „лингвистичкији” део науке о језику, који обично обухвата граматику, лексику, а мање фонетику и семантику, да не говоримо о другим нивоима, чини се, утичу и на неке сасвим погрешне ставове о односу међу дисциплинама. Никако се, на пример, не можемо сложити са Фолијевим постављањем граница између лингвистике, социолингвистике и лингвистичке антропологије, па макар ублаженим речима да оне нису ни “апсолутне” ни „оштре”, Foley 1997). Он, наиме, илуструје разлику између тих дисцплина дајући типичан пример из социолингвистике о употреби наставка за герунд у енглеском, где се лингвистика зауставља на „описивању” могућег различитог изговора /-in/ или /-ing/, социолингвистика ће се позабавити корелацијом једне од варијанти са неком социјалном групом (према полу или према класној припадности), док би антрополингвистички посао био да се упита: „шта означавају говорници када употребе једну од тих варијанти?” На крају, он ипак цитира социолингвистички закључак да се употреба /-ин/ облика од стране припадника средње класе некада користи за испољавање обележја радничке класе, као што су 'мушкост', 'мужевност', ‘физичка спремност', и сл. (Foley, 1997: 3-4) Претпостављамо да се овакво смештање лингвистике у простом навођењу облика без директне везе са укупним језичким и социјалним значењима и фунционисањем, може приписати англосаксонској (америчкој) традицији која је у једном периоду своје историје, у време дистрибуционализма, довела „формализам” и брисање семантике до карикатуралних граница, што ипак није случај са другим лингвистичким традицијама.

О сужавању лингвистике на „без-значењску” науку налазимо бројне тврдње и код оних чија је оријентација пре 
свега лингвистичка. Тако у литератури о превођењу, на пример, Баснет (2005:23) сматра да је боље, иако је лингвистика у основи превођења, рећи да превођење припада семиотици, да је „уско лингвистички приступ” недовољан, и да преношење поруке поред граматике и лексике, мора да обухвати и низ екстралингвистичких критерија. Слично каже и Тер-Минасова - да знање и свест о ,значењу речи и правилима граматике није довољно” (Тер-Минасова, 2008, 35), већ је потребно познавати и шири контекст.

Као последица таквог схватања односа лексике и граматике и значења, Баснет (ibid: 39) преноси исти став на разлику између језичке и културне (не)преводивости. Под „чисто” лингвистичком непреводивошћу она разуме следеће: лексичка и синтаксичка замењивост оригиналног исказа у смислу дословног превода, или превода реч по реч, готово је немогућа. Тако на пример, немогуће је дански исказ: Jeg fondt brevet превести дословно на енглески, јер одређени чланови у данском и енглеском заузимају различита места у реченици (у енглеском члан jе пре именице: I found the book). Иако тврди да је овај критериј јасан и да нема потребе за даљим објашњењима, ипак мислимо да је неопрезно тако окарактерисати “лингвистички" превод. Заправо се ради о готово карикатуралном поимању језика, што потврђују многи примери које је Марк Твен (Twain) дао у свом осврту на „ужасни немачки језик”, између осталог карикирајући граматички род именица: In German, a young lady has no sex, while a turnip has. Када је у питању морфосинтаксичка дистрибуција, жали се на раздвајање глаголских морфема, а пример како би то бесмислено изгледало даје раздвајајући енглеску реченицу и енглески глагол departed по немачком моделу:

"The trunks being now ready, he DE- after kissing his mother and sisters, and once more pressing to his bosom his adored Gretchen, who, dressed in simple white muslin, with a single tuberose in the ample folds of her rich brown 
hair, had tottered feebly down the stairs, still pale from the terror and excitement of the past evening, but longing to lay her poor aching head yet once again upon the breast of him whom she loved more dearly than life itself, PARTED."

Ако је и опростити Марку Твејну за његово духовито, али ипак лаичко неразумевање граматичких категорија, и можемо његов есеј о немачком посматрати као инспиративан за размишљање о другом језику наслањајући се на модел свог језика (Magnusen, 2003: 125), не можемо ипак да се не осврнемо на чињеницу да се уопштавања о „чисто лингвистичком преводу” или „чистој лингвистици” своде на таксономију и редослед форми које немају никаквог ни смисла ни функције.

Озбиљан проблем настаје у лингвистици када се механички постављају односи међу језичким јединицама из различитих језика. Тако, мада у контексту одбране природног семантичког метајезика, Вјежбицка (Godarrd i Wierzbicka, 2014:15-16) наводи расправу са другим једним лингвистом о тумачењу „егзотичног” језика пираха. Проблем настаје јер њен опонент не прихвата да је једна реч: ogi- полисемична у том језику, и увек је преводи дословно са big или bigness, чак и у контексту, у коме та реч има друкчије значење - „сви”:

'igihí hi 'ogiáagaó 'oga hápií . . .

man he bigness field went

'The men all went to the field.'

Није без значаја рећи да се овакве недоумице и, сложићемо се с Годаром и Вјежбицком, недостаци у опису, могу пронаћи у случајевима веома малих језика какав је пираха (један од 170 језика у Амазонији, чији број варира од 3 говорника до неколико десетина хиљада), који има око 250, а можда и само 100 говорника, а подаци о њему се могу наћи обично код једног до двоје истражи- 
вача. Управо зато што су то непознати језици читалачкој популацији лингвиста, и увек када се претпоставља да је читаоцу непозната граматичка структура језика, прибегава се глосирању, избором сегмената речи и означавањем, колико је могуће прецизније за дату граматичку тему, категорија: на пример, у једном од амазонских језика:

$\mathrm{Wa}^{3}-\operatorname{lin}^{3}-\mathrm{su}^{3}-\mathrm{ai}^{2}-\mathrm{a}^{2}$

manioc-Cl:BONE.UKE-DEF.CURRENT

'This manioc root which we both see before us now.'

(Dixon and Aikhenvald, 1999, 282)

Међутим, овакво глосирање какво видимо у другом реду случајно одабраног примера свакако није исто што и превод, што потврђује и „слободан” превод у трећем реду, како је уобичајено у лингвистичкој литератури. Стога се тешко може прихватити да је интерлинеарни, реч по реч, превод у чисто лингвистичком смислу, било шта друго осим информација о лексичко-граматичкој структури намењен другим лингвистима.

\section{Лексикичко-културолошки континуум}

Поставља се питање онда, може ли се и како повући граница између чисто лингвистичког и културног. Покушаћемо да одговоримо на то питање у вези са лексемама, односно речима као једном од кључних језичких феномена, што не значи да и граматика не може да се тумачи у вези с културом, (уосталом на њој је заснована теорија о релативности Сапир-Ворфа), међутим то би далеко превазишло границе овог рада. Стога ћемо се осврнути на оне лексичке појаве које су више или мање „културно обележене“, у настојању да прикажемо континуум културне обележености речи. Јер, како кажу Годар и Вјежбицка (2014: 2), речи су „код” који треба разбити, а осим тога сви језици света 
имају реч за ,реч”, док многи језици немају своје речи за „реченицу”, „граматику” или „глас” (ibid: стр. 4.), што показује њихов језички и културолошки значај.

У наредним редовима прво ћемо посветити пажњу оним лексемама и лексичким јединицима које су у литератури уско и неизоставно повезане са културом, и можемо их назвати „културно условљеним лексемама“ или „културно обележеним” или „културемама”, а потом и „основним” и свакодневним лексемама за које се мање везује културолошка слика неке језичке заједнице. Дакле, сматрамо да можемо говорити о континууму културолошке маркираности лексички јединица.

\section{Културеме}

Неке језичке, лексиколошко-семантичке јединице готово се неизоставно у литератури везују са културом. То могу бити фразеологизми (идиоми), пословице, изреке, крилатице, цитати, игре речима и сл. Културолошка обележеност тих лексичких (језичких јединица) посебно је важна у превођењу, јер треба тражити, и пронаћи, ако је могуће, одговарајући превод за скуп речи које се употребљавају углавном у истом облику, често са метафоричким значењем, а значење није композиционално, односно не могу се преводити појединачне речи, већ целина. Најда наводи пример афричке пословице: "People who hunt elephants never sleep cold" која нема никакве везе са „слоновима” и „хладноћом”, већ се односи на позитивну особину људи који напорно раде па од тога имају пуно користи. (Nida, 2001: 38)

Како каже Јовановић (2006: 18), пословице се проучавају кроз различите „спољашње приступе” као што су: „Психолошки, социолошки, компаративни, семиотички, функционални, прагматички, културолошки, комуниколошки”. Овај плурализам приступа има за последицу, и у лингвистичким и нелингвистичким дисциплинама, раз- 
личите ставове о њиховом лингвокултуролошком значају. Следеће редове посвећујемо анализи тих ставова.

За пословице, изреке и сл., лингвисти Годар и Вјежбицка (2014:184-204) тврде да се (осим у паремиологији) мало изучавају у лингвистици. На почетку дају уопштен увод о повезаности пословица са културом, о њиховој улози у преносу културе с генерације на генерацију, употреби, као врсти апстракције, односно аналогије којом се може приказати нека посебна ситуација, а назива их чак и „моделима културног знања". Њихова даља анализа је свакако веома интересантна, јер настоје да се „семантика” пословица, изрека и сл., искаже природним метајезиком, што успевају у великој мери. Тако, на пример, „пословица” се

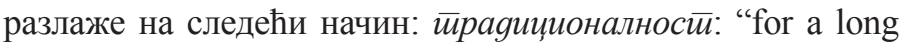
time before people said these words at many times, when they wanted to say something like this", па даље следи одређење

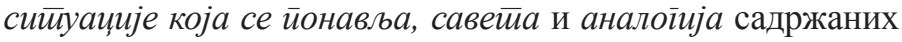
у семантици лексеме йословица, и сл. Ипак, у прилогу тог поглавља, у коме су анализиране малајске пословице, звездицом остају забележене „комплексне лексеме” попут:

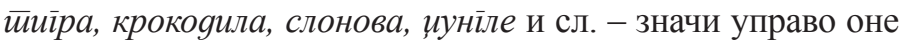
лексеме које су културолошки обојене, (у малајским пословицама, ibid: 204), а звездица у њиховој семантичкој анализи обично означава потребу даље семантичке деконструкције лексема на примитиве, док су овде само назначене као културно и контекстуално зависне. Дакле, на тај начин, а и даље, својим експлицитним тврдњама, кажу да остају „питања културе", односно "resonance and associations of the words”, што илуструју разликом између ,,аграрног лексикона енглеских пословица" и „узгајања пиринча и рибарења" у случају малајских пословица. (ibid: 200).

Ван лингвистике такође остаје културолошка употреба и функција пословица које се мењају током историје, те цитира Obelkevicha (1994, у: Goddard and Wierzbicka, 2014: 200) који сматра да је ренесанса опчињена пословицама, а просветитељство их потискује, док се у модерно 
доба чак сматрају и табуом, осим ако не постану материјал за шалу појединца (вероватно као антипословице). У фусноти, на страни 194, цитира Sweeney-a (1987: 97 u Goddard and Wierzbicka, 2014:194), како је пред-модерно малајско друштво било обележено не само „формулаичким дискурсом” већ и „формулаичким мишљењем”. Такво цитирање потенцира спољашњи, нејезички приступ овим културемама, мада су формулаички изрази и искази у суштини сасвим природни за било које друштво пре појаве писмености, не само малајско, те цитирање таквог става не чини нам се умесним, јер разликује једно друштво у време пред-модерно, каква су и сва друга друштва. Наиме, опште је познато да је у усменој култури потребно за преношење знања имати и формулаички и естетски (поетски) пријемчиве исказе или дискурсе, те није чудно да су такве културе богате традиционалним исказима попут пословица, поезије, загонетки и сл. Како каже Онг (2002) за особе које су неписмене, ма колико да не испољавају исте вербалне и мисаоне обрасце као писмене особе, погрешно је мислити да „орално” мишљење није веома софистицирано и дубоко мисаоно. То доказује и примером врло комплексних објашњења које Навахо наратори усмених фолклорних прича дају у вези са разумевањем комплексних животних ситуација као и симболичких импликација (Онг, 2012: 32). Чињеница да и лингвисти овако штуро (цитатима) потенцирају овај културно-историјски аспект пословица доприноси њиховом још дубљем смештању у „скривени” културни слој интеркултурне комуникације. Наравно, може се показати да пословице итекако остају (наравно не све) и у наше време (видети у: Половина и Кашић, 2017)

Пословице у литератури о интеркултурној комуникацији често буду нека врста доказа или потпоре изучавању и закључивању о културним разликама међу народима и групама људи. Тако Воронов и Сингер (2002) наводе у вези са дистинкцијом „индивидуалистичке” и „колективистичке" културе, рад Но and Chiu (1994, y: Voronov and 
Singer, 2002: 463), који су анализирали скоро десет хиљада кинеских пословица и после анализе њиховог садржаја, посебну пажњу посветили оним пословицама које исказују однос према наведеним двема категоријама. Њихов закључак је био да иако већина изрека исказује „колективистички" став, ниједна од оних које исказује индивидуалистички став није негативна према индивидуализму. На основу таквог истраживања закључују да се Кина не може сматрати чистим „колективистичким” друштвом. То истраживање је даље употпуњено анкетом студената у Хонг Конгу, и тако додатно потврдило да њихови (кинески) и “кооперативни” али и „индивидуалистички” ставови пре говоре о синтези тих аспеката културе, него што се могу сврстати у овај или онај тип. Такође је проблематично то сматрати неком трајном културном одликом, а још мање неком променом која је последица „вестернизације”, већ пре утицајем демографских фактора, образовања, врсте посла и односа руралног и урбаног (Voronov and Singer: 468). Овакве културне разлике су, дакле, варијабле зависне од друштвених услова, а не фактори који утичу на понашања, ставове, веровања. Занимљив је пример који наводе Воронов и Сингер (стр. 475) о „индивидуалистичком” и „колективистичком” понашању у две ситуације: на велепродајама пиринча и пијацама гуме, где је понашање сасвим различито, иако се ради о припадницима исте културе. Поента њиховог рада је критика међукултурне психологије, јер сматрају да недостају систематски подаци и недовољно јасно мотивисани закључци о међукултурним разликама.

Сличну потпору коју пословице дају психолошким одређењима једна националне (традиционалне) културе налазимо и у следећем цитату нашег познатог психолога Требјешанина (2008:80):

„Дете се схвата као неразумно, немирно, неваљало, асоизјално, неморално сииворење, које се само присилом, сиироіим васиийањем може довести у ред и од њега направити разумно, сочијално, йослушно, мирно, морално, 
gобро и куличурно љуяско биће: „Дијеше мноїо миловано ниїga gобро оgі̄ојено.” Срби су вековима сматрали благо, либерално васпитање глупошћу и презриво га називали

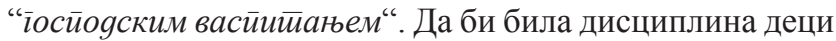
треба физичким кажњавањем, батином “утерати страх у кости“. Ово стереотипно мишљење о блаїойворном gејсииву байина као моћног васпитног средства изражавају пословице: „Дијетее небијено слабо оgіојено”, „Ко није йучен, није научен”, „Байина је из раја изашла”, „Љескова масй је чудойворна".

И овде би се могло рећи да се овакво “стереотипно” мишљење о српским схватањима кроз векове пре могло објаснити утицајем социјално-економских фактора, (социјална организација многобројне породице у прошлости), а да није на пословицама да одреде став једне културе према деци, може да се види и из оваквог, малог, одбира пословица (преузето из Јовановић, 2006, II)

„Ако је и најі̄оре gијетие, оиети је рояительима мило; Док gијеие не зайлаче, майи іа се не сјећа; Као злайна јабука ( Вук: „Рече се н. п. за лијепо дијете); Као лане (Вук: „Рече се за здраво мало дијете"); Пјанциа и gијешие Бої чува; Да Бої ђетету не gа оно шито му ойаи и майи мисле! Ђеца, буgале и йијани ирравgу іоворе; Ђеца се чуgе свачему, а луgи ничему; Мала ђеца мала бриїа, велика ђеца велика бриїа; Ко с ђецом сиии, иолитиан освиће; Позна ђеца

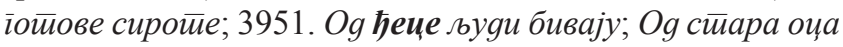
ђеца сирочаg; 4454. Прва се ђеци gаје; Тако ми Бої ђецу сачувао! У йврgа оца краяљива Ђеца; Ђеца су као роса; Шӣо чине Ђеца, ийо вияе оg оца.

Видимо да ове српске пословице приказују дете и као лепо (злайна јабука, лане); и наивно (поређење с ,ијанцуем”, „чуgе се свачем”), као и одговорност, бригу родитеља за децу (мала ђеца мала бриїа; оg стиара оцуа ђецуа сирочаg). Дакле, као што је и уобичајено код пословица, има их које се баве и позитивним и негативним аспектима сличних ситуација, а некад чак могу да буду и контрадикторне. 
Постоји још један тип културема - исказа који су културно обележени, а то су крилатице. Оне су везане за примарни културни контекст из којег потичу, истовремено су и алузија на њега, а познавање примарног контекста најчешће и предуслов за правилно разумевање или бар употребу крилатица. Иако се најчешће везују за библију, књижевност, и речи значајних историјских личности, говора и сл., данас рекламни слогани, филмови, песме и телевизијске емисије, изјаве политичара и сл., све више постају извори крилатица.

Међутим, овакав тип културема, као што су крилатице, нису нужно разумљиве целокупној језичкој заједници. Питање је да ли би, рецимо, сви говорници српског језика разумели исказ: „Вози, Мишко” који се може чути у одређеним ситуацијама, и повезати га са одређеним филмом и схватити хумористичку ноту коју носи собом. Још је драстичнији пример америчке крилатице или, како је сад називају, мемеом (у нашој штампи се понекад по енглеском моделу та реч изговара „мим”): „Kilroy was here”. Напоменимо да ова крилатица иде уз цртеж човека са издуженим носом који гледа преко неког зида. Иако нико не зна поуздано одакле потиче исказ, нити је значење сасвим јасно, те је отворена за разна тумачења, највероватније објашњење о њеном настанку свакако представља лепу причу. Дакле, могуће је, према тој највероватнијој верзији порекла крилатице, да је Килрој био инспектор једног америчког бродоградилишта у време Другог светског рата, који је, да би знао шта је прегледао, на деловима бродова исписивао ту реченицу. Када би брод испловио, војници би почели да примећују тај натпис, а затим су и сами војници почели да исписују ту крилатицу са цртежом на разним површинама. Након рата, војници су пренели овај меме у своје земље (савезничке) а потом се проширио и као урбани графит (Shifman, 2014, 24-26)

Док су пословице и крилатице готово неспорно културно обележене лексеме, постоји низ свакодневних 
лексема, које су појединачне, али које се такође често сврставају у ову категорију. Тако се у литератури врло често, одмах након тврдњи о повезаности друштва, културе и језика, помињу речи које спадају у домен хране. Обимна литература које се бави културно-антрополошким и језичким аспектима исхране сама за себе би могла представљати предмет анализе како аутори успостављају однос између језика и културе у њој. Овде ћемо се вратити на већ цитиране ауторе. Годар и Вјежбицка (2014: 8) кажу да су то очигледни (obvious) примери културема. Тако пољски има речи за чорбу од купуса: bigos, чорбу од цвекле: barszcz, и пекмез од шљива: powidła, док тога у енглеском нема. Али зато у енглеском постоји реч за џем од наранџе: orange jam(marmalade), јапански има реч за јако алкохолно пиће од пиринча: sake. И јасно, такве речи говоре нешто о култури исхране тих народа. И Катан сматра да су посебно интересантне културеме, које се чак могу у превођењу оставити у оригиналу, јер то омогућава да се и у преводу осети нека врста локалне обојености. Међукултурни сусрети су све чешћи у наше доба. Стога је могуће данас наћи такве различите културе и у удаљеним градовима, као и терминологију пренесену из једне у другу средину (данас имамо суши барове, йицерије, кебаб ресторане у Београду). А наравно, поставља се и питање реалија, односно чак и ако преведемо хлеб са крух, bread, pain, pano итд., да ли се ради о истим реалијама. И Баснетова даје такве примере културема: руска реч сыр, када се преведе на енглески: cootage cheese, опет уствари није исто. Слично томе, наводи да енглески butter и италијански burro немају исту функцију и значај, јер је у енглеском путер и знак квалитета и стандарда, насупрот маріарину. Можда најбољи пример код ових аутора о преношењу „мириса” и „укуса” у другу културу наводи Катан (Katan: 84). Ако преведемо: “Un ristretto, doppio, caldissimo, - disse al cameriere." на енглески, можемо рећи: strong, double, hot coffee, што је уобичајеније, или: “А concentrated, double, 
very hot', she said to the barman". Ова последња варијанта боље преноси мирис и укус, по мишљењу аутора.

\section{Осн \\ овне и свакодневне речи}

Док смо у претходном одељку указали на низове изразитих културема, у овоме ћемо одељку пажњу посветити речима које у већини граматика и/или лексиколошкој литератури немају увек статус културема, али по свом значају за поређење друштва и културне организације заједнице, или на различито поимање стварности у различитим културама, добијају посебно место у дискурсу о интеркултурној комуникацији. То су лексеме у оквиру лексичких поља: људи, сродства, назива животиња и биљака, боја, затим апстрактнијих (унутарњих) појава: емоција, когниције и сл. С обзиром на обимну литературу која прати све овакве теме, пажњу посвећујемо овде само томе како и зашто се остварују и као културеме.

Разлог томе је што многи сматрају, заједно са Гордар и Вјежбицком (2014: 39) да значења речи, мада су пре свега концептуални феномени, имају „социјалну и културну” основу (underpinnings). Стога описи значења морају обухватити и „прототипична когнитивна и мотивациона сценарија”, а шире посматрање контекста речи (колокације) нам говори о културним стереотипима, представама и уопште о културно специфичним а комплексним значењима. Настојећи да открију семантичке универзалије, и то путем универзалних семантичких примитива, Годар и Вјежбицка се баве међујезичким поређењем термина за човека, и утврђују да су „људи, жене и деца” вероватно универзални, док „мушко, женско, дечак, девојчица” то нису (има језика који имају само термине за човека и жену, али немају посебне за дечак и девојчица, дакле не познају разликовање према узрасту унутар категорије). Други, али такође лингвокултуролошки приступ има Штасни (2013), која се 
бави номинацијом човека и низа лексема из тог домена у српском језику, одређујући, између осталог, појмове које означавају те лексеме позитивним и негативним карактерним особинама, именовањем човека према интелектуалним својствима, са развијеним и умањеним умним способностима, и именовањем човека према физичком изгледу, са основним естетским категоријама: лепо и ружно.

Уско повезано са лексиком о човеку је и обимна антополингвистичка литераурља о сродству (видети рецимо у Foley, 1997). Јасно је да у превођењу, на пример, веома једноставне речи попут uncle, aunt на енглеском може представљати проблем у превођењу на српски, јер на српском прва реч може бити: ујак, сиириц, йеча, а друга:

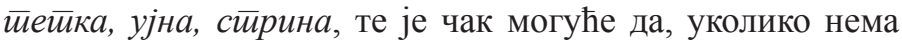
релевантне информације негде у тексту, преводилац остане до краја у недоумици како да преведе неку од тих речи. Дакле, међукултурне разлике се веома лако уочавају већ на овом плану.

С друге стране, у више антрополошки оријентисаним приступима, како каже Фоули, (Foley, 1997: 131) анализа семантичког домена сродства је радо анализиран феномен јер може да докаже универзалистичке или релативистичке ставове о односу језика и културе. Разлог том интересовању налази се у чињеница да је феномен сродства биолошки условљен - за опстанак људске врсте од суштинског значаја је репродукција која има своју природну, биолошку основу. Међутим, док се за лексичка поља 300 и фито класификације, а поготово за боје, претпоставља универзална биолошка, перцептивна и когнитивна основа заједничка свим људима, таква перцептивна и когнитивна својства човека нису од истог значаја када су у питању сродници, јер, једноставно, наши крвно блиски сродници не морају, и најчешће, нужно не личе једни другима на исти начин на који се спектар боја „приказује” сваком човеку. Може се стога претпоставити да основна, ужа, нуклеарна породица, која је, како се то обично каже, 
од значаја за развој детета, за његову социјализацију, заправо представља неку врсту заједничког искуства људи. Ипак ,неслагања постоје, те једни тврде да биолошка основа није кључни фактор у категоризацији сродства, већ је то културолошки условљен феномен, док други сматрају да и ту постоји ипак биолошка, те стога и универзална основа. (Foley: 132-133). Трага се и за универзалним базичним односима, па се тако сматра да су „мајка”, „отац”, „дете” базичне јединице у свим системима сродства, и то пре свега из биолошких разлога. Међутим, док је „мајка” релативно универзална сема у језицима света, концепт „отац” је мање лексикализован у језицима света (Goddart and Wierybicka, 2014). Степен раслојености ових лексема у интеркултурној комуникацији (као што је, уосталом, случај са многим другим лексемама) може се посматрати и у оквирима међукултурне варијабилности унутар једног националног језика. (Бјелетић, 1994)

Разлог што су ове лексеме човека и сродства добиле толико значаја у интеркултурним истраживањима могу се приписати антопоцентричности језика, као и антропоцентричности хуманистичких наука, јер су те лексеме битне и у целокупној култури: религији, социјалном устројству, међуљудским односима, итд. Међутим, и други типови ,једноставних" речи често долази у оквире интеркултурне комуникације. Тако, Баснетова каже да се чак и врло једноставне речи афирмације или кратких поздрава представљају проблем (oui, si, ja) јер је код Италијана, Француза и Немаца уобичајеније да се дуплирају и триплирају у разговорном језику, па само једном преведено са енглеским yes може деловати превише оштро. Дакле, треба наћи одговарајућу „афирмацију” или „поздрав”, јер поступци превођења подразумевају и одговарајући контекст.

Начин поздрављања и обраћања је истраживан такође у разним дисциплинама (етнолингвистичкој, социолингвистичкој, прагмалингвистичкој и сл.), а начин превођења поздрава и речи садржаних у поздравима има дугу историју. Навешћемо само да су се око таквог једног пре- 
вода поздрава, још пре пет векова, водиле расправе. Ради се о преводу Мартина Лутера, који је поздрав: Ave Maria gratia plena, превео на немачки језик тако што је уместо да преведе са “Зgраво Марија, йуна милосиии”, он превео ca: "Gegrüßet seist du, Maria, du holdselige", (Зgраво Mapuja, gраїa моја.)”, са објашњењем да је у немачком сасвим природно рећи „драга”, „мила”, јер то одговара духу немачког језика, и природном поздраву при сусрету, али и оригиналном контексту (хебрејском). А када се преводи, по Лутеровом мишљењу, постоји низ варијанти из којих се могу одабрати речи, и треба их потражити тако да одговарају датој ситуацији. (Stolt, В. 2014. 381-383)

Нису само поздрави важни у обраћању међу саговорницима. У социолингвистици, тако и у интеркултурној комуникацији, често се говори о употреби личних заменица за друго лице: ТИ/ВИ. Литература о овом питању је пребогата. Могу се наћи културни обрасци на националном и етничком нивоу (на пример, код нас се чак налази учтива употреба они за обраћање код Словака и кад говоре српски), али је интересантно и када се дешава смена једног и другог облика у зависности од ситуације. Тако се, рецимо, заменица они, како су у једном нашем истраживању рекли испитаници у анкети, користи у маркираним значењима: „кад сам у свађи с неким”, „као у ругању”, „у иронији”, чак и у „разговору разведених, бивших супружника", а радило се о млађим информантима. (Половина, 1983). То може да се објасни преношењем културно-језичког модела (немачког) на друге средине. Или се промена дешава на ширем социјалном контексту. Тако у шведском, Паулстон (2005) објашњава како се употреба заменице $d u$ без употребе имена, која је необична за ту средину, за разлику од енглеског језика, као релативно скорија појава, развила због „националне политике друштвеног егалитаризма" (Paulston, 2005:206).

Оваквим тумачењама и закључцима, који се у литератури везаној за интеркултурну комуникацију дају у вези са одликама и разликама међу културама на основу језич- 
ких појава, треба увек унети ноту опреза. У том смислу, можемо да додамо још један пример „мале” речи, „прве” речи детета која је била значајна у одређивању става према детету у самоанској култури. Ochs (2005:82) наводи да је „прва реч” детета у самоанској култури: tae. Али је та реч и део псовке, и та чињеница је један од разлога што људи око детета, па последично и самоанска култура, конструишу и третирају дете као дрско биће, неваљало, као „псовача". С обзиром да су први слогови код све деце света комбинација прекидног консонанта и вокала (ба, $\bar{u} a, м a$ и сл.), овакви коментари самоанских одраслих говорника су пре уобичајена шала на рачун случајног поклапања првих слогова „прве речи” и првог слога псовке (јер, самоанска реч за „тату” је tama, а општепознато је да прве речи детета често настају елидирањем неког слога у односу на реч одраслих - те настају два хомонимична облика). Чак и одломак разговора са једном самоанском мајком јасно показује да мајка инсистира на шаљивом тумачењу изговорених слогова: he doesn't REALLY mean tae...And so the people ((empathic particle)), we-we as adults, што каже уз чест смех. Чињеница да више самоанских говорника то истиче ни најмање не говори о томе да таква хомонимија има утицаја на њихове ставове о детету. Случајеви таквих језичких хомонимија су увек предмет хумора (и то не баш инвентивног). Стога сматрамо да придавање значаја оваквој речи не може да допринесе ни на који начин тврдњама да је однос према детету условљен том речју (однос може бити такав, али се то може утврдити на основу других показатеља).

\section{Уместо закључка}

Неколико последњих примера лексема, које спадају у граматику и лексику разговорног дискурса, указују на још један домен истраживања, чест у истраживању интеркултурне комуникације, а то је начин вођења разговора, 
дискусије и дебате у различитим социјалним и културним контекстима. Многа истраживања се баве анализом различитих типова комуникативних дискурса у интеркултурној комуникацији. Но, иако смо се у овом раду позабавили пре свега лексичким континуумом према његовој културолошкој условљености, и односом према језику у научном дискурсу о интеркултурној комуникацији, напомињемо да се и у сфери анализе интеркултурних дискурса често полази од различитих, појединачних лексема или неког лексичког домена да би се дошло до типологије или неких других закључака о односима унутар њих. Сматрамо да је потребна методолошка опрезност и у даљем разграничавању места језика у дискурсу интеркултурне комуникације, и да лингвистика, која упркос неким мишљењима која је ограничавају, заузима значајно место како својом методологијом и тако и приступима када се ради о месту језика у интеркултурној комуникацији.

\section{Литература}

Allwood, J. 1985. "Untercultural Communication " in Allwood, J. (Ed.) Tvärkulturell kommunikation, Papers in Anthropological Linguistics 12, University of Göteborg, Dept of Linguistics.

Baldwin, J.R., Means Coleman, R.R. González, A. and Shenoy-Packer, S. 2014, Untercultural Communication for Everyday Life. Wiley, Blackwell, Malden, MA

Bassnett, S. 2005.Translation Studies, Third edition, London and New York, Routledge, Taylor \& Francis e-Library.

Марта Бјелетић, 1994, „Терминологија крвног сродства у српскохрватском језику“, Јужнословенски филолої, 199-207.

Dixon, R. M. W. and A. Aikhenvald (eds.), 1999. The Amazonian Languages. Cambridge: Cambridge University Press.

Dixon, R.M.W. and Aikhenvald, A.Y., 1999. Amazonian languages, Cambridge, Cambridge University Press.

Ochs, E., 2005. Constructing Social Udentity: A Language Socialization Perspective, in: Kiesling, S..F. and Christina B.Paulston (eds.) 2005. Untercultural Discourse and Communication. The Essential 
Readings. B Malden, MA, Oxford, UK: Blackwell Publisheing Ltd. Str. 78-92.

Foley,W.,1997. Anthropological Linguistics: An Mntroduction. Wiley-Blackwell.

Goddard, C. and A.Wierzbicka, 2014. Words and Meanings. Lexical Semantics across Domains, Languages, and Cultures. New York, Oxford University Press.

Hall, E.T. 1959. The Silent Language, new York: Double Day \& Company

Katan, D. 2009, Translation as intercultural communication, in: Munday, J. (ed) The Routledge Companion to Translation Studies, str. 74-92. London: Routledge

Kiesling, S..F. and Christina B.Paulston (eds.) 2005. Untercultural Discourse and Communication. The Essential Readings. B Malden, MA, Oxford, UK: Blackwell Publisheing Ltd.

Magnusson, G. 2003. Unterlinear Translation and Discourse à la Mark Twain in: (Anderman, G. and Rogers, M. eds,) Translation today, Trends and Perpsectives. Multilingual matters, Clevedon, UK

Munday, J. (ed) The Routledge Companion to Translation Studies. London: Routledge

Walter J. Ong, Orality and Literacy : The Technologizing of the Word, 30th Anniversary Edition

With additional chapters by John Hartley. London and New Zourk, Routledge.

Nida, E.A., 2001. Contexts in Translating. Amsterdam:John Benjamins Publishing Company

Nida, E.A. and Taber, Ch.R. 1982. The Theory and Practice of Translation. ( $2^{\text {nd }}$ reprint). Leiden:E. J. Brill.

Panić Cerovski, N. 2017. Verbalna i neverbalna komunikacija. Beograd: Filološki fakultet.

Paulston, C.B. 2005. Pronouns of Address in Swedish: Social Class Semantics and a Changing System, str. Un Kiesling. 198-217. Kiesling, S..F. and Christina B.Paulston (eds.) 2005. Hntercultural Discourse and Communication. The Essential Readings.B Malden, MA, Oxford, UK: Blackwell Publisheing Ltd.

Половина, В. И Кашић, 3. (2017). Синхронијска анализа употребе и функције пословица и изрека, Анали Филолошко̄ факулиемей , 29/1, 149-164..

Polovina, V. 1983. Upotreba jednine И množine ličnih zamenica u obraćanju sagovorniku u savremenom srpskohrvatskom jeziku, Naučni sastanak slavista u Vukove dane, MSC, 13. Str. 185-192.

Rogers, E. M. (1994). A history of communication study: A biographical approach. New York, NY: Free Press. 
Rogers, E.M. and Hart, W., Miike, Y. 2002, Edward T. Hall and The History of Untercultural Communication: The United States and Japan, Keio Communication Review No. 24,

Schifman, L. 2014. Memes in Digital Culture. Cambridge, MA: Тhe МИТ Press.

Stolt, B. 2014. Luther's Translation of the Bible, Lutheran Quarterly, ХХУИИИ: 373-400.

Tolstoj, N. И., 1995, Jezik slovenske kulture. Niš: Prosveta.

Trebješanin, Ž. 2008. Predstava o detetu u srpkoj kulturi, Sofos, Beograd.

Twain, Mark, The Awful German Language. Preuzeto sa interneta: https://www.cs.utah.edu/ gback/awfgrmlg.html

Voronov, M Singer, J. A., 2002. The Myth of UndividualismCollectivism:A Critical Review, The Journal of Social Psychology, 2002, 142(4), 461-480.

Yoshitaka Miike, 2016. Editorial, Asian communication studies at the crossroads: A View to the Future from an Asiacentric Framework, Journal of Content, Community \& Communication, Vol. 3 Year 2, June - 2016 Amity University, Madhya Pradesh (ИSSN: 2395-7514), str. 1-6.

Дурбаба, О. 2016. Кулимура и насииава стираних језика. увоg y иниееркулимурну йриењену линївистиику. Београд: Филолошки факултет.

Јовановић-Симић, Ј. 2006.

Тер-Минасова, С. Г. 2008, Языки межкульйурная коммуникация, (3-е издание), Слово: Москва: МГУ

Толсто́й Н. И., 1995. Язык и нарояная кульйура. Очерки йо славянской мифолоїии и етинолинївисииике. Индрик, Москва

Штасни 2013: Gordana Štasni, Reči o čoveku, Novi Sad, Filozofski fakultet, 2013.

Хлебец 2012: Boris Hlebec, "Where Boys, Girls and Children Come From", Studia Anglica Posnaniensia: Unternational Review of English Studies, 47/2-3, Berlin, 2012, 59-68. 


\section{Prof. Vesna Polovina, $\mathrm{PhD}$ \\ University of Belgrade Faculty of Philology}

\section{ON LANGUAGE IN THE DISCOURSE ON INTERCULTURAL COMMUNICATION}

\section{Summary}

The paper first situates language and linguistics within intercultural discourse by briefly pointing out the historic links between the teaching of foreign languages and translation theory and practice in the history of intercultural communication as a discipline. Next, the literature dealing with the problem of the position of language in relation to other semiotic, cultural phenomena has been analyzed. The central part of the paper is a critical overview of the place of language phenomena, in particular regarding the lexicon of the language, which, according to the texts dealing with the intercultural discourse, can be seen as a continuum, starting with strongly culturally entrenched lexemes towards "basic", "ordinary", "everyday" lexemes, showing that, in the long run, the culturalness of a lexicon is only a matter of degree, and not a polar distinction. Therefore, caution is desirable in how we put boundaries between linguistic and intercultural or at least in how we draw conclusions on the intercultural differences and intercultural communication.

Key words: language, lexemes, discourse, intercultural communication 